\title{
1 When an insecticide affects the adaptive value of intraguild 2 predation by an invader
}

3

17 Corresponding author

18

\&These authors also contributed equally to this work Est. Saint-Bruno de Montarville, Québec. Canada

\section{E-mail: pcabrerablanco@outlook.com (PC)}

IThese authors contributed equally to this work

2 : Institut de recherche et de développement en agroenvironnement. 335, rang des Vingt-Cinq 
25

\section{Abstract}

$$
\text { Biological invasions can generate major ecological disturbances, such as changes in species }
$$

diversity and structure of communities. It is believed that the multicolored Asian ladybeetle, Harmonia axyridis Pallas (Col, Coccinellidae), recognized as one of the most invasive insects in the world, has reduced native coccinellids populations in several areas and is considered as a threat for biodiversity at large. A significant trait, favoring its invasiveness and its dominance over indigenous ladybeetles, is intraguild predation (IGP). IGP has advantageous adaptive value for individuals, removing competitors, potential predators and providing an alternative nutritive resource, when main resources are scarce. Previous research demonstrated that this invasive ladybeetle is highly susceptible to the reduced-risk insecticide novaluron, a chitin synthesis inhibitor, whereas the North American indigenous competitor, Coleomegilla maculata DeGeer (Col, Coccinellidae), is not. Our study explores the adaptive value of IGP for each of the two coccinellids after preying on each other's larvae, previously treated with insecticide. Our first hypothesis is that the invasive ladybeetle, susceptible to the insecticide, should lose the adaptive value of IGP, while the native predator not. Our second hypothesis is that the adaptive value of IGP for the invasive predator will be recovered over time, as a result of neutralisation of the insecticide by the intraguild prey (native species). The results support both hypotheses, and show that an insecticide can completely remove the adaptive value of IGP for the invader, while it does not change for the indigenous ladybeetle. Moreover, the study demonstrates that

4 if the intraguild prey (non-susceptible to the insecticide) undergoes molt after being exposed to the insecticide, the adaptive value for the intraguild predator is restored. 


\section{Introduction}

Biological invasions can interfere with several ecological and evolutionary processes [1],

such as changes in species diversity and structure of communities [2], affecting ecosystem services and causing huge economic losses [3-5]. Some of the traits that characterize invasive species are high adaptability to changes in the environment, high fecundity and dispersion [6,

51 7], and broad diet range [8-10]. Another factor contributing to the success of invaders is competitive ability, and more specifically intraguild predation (IGP) [11-14]. IGP, is defined as

53 the predation on a competitor [15], and confers adaptive advantages for of the intraguild

54 predator. These include removal of competitors, removal of potential predators, and an alternative nutritive resource when main resources (extraguild prey) are scarce. Therefore, IGP

56 has important consequences for the distribution, abundance, and evolution of species involved

57 (intraguild predator, intraguild prey and shared resource) [16] as well as for applied topics such as conservation management and biological control $[17,18]$.

The multicolored Asian ladybeetle, Harmonia axyridis Pallas (Col., Coccinellidae), widely recognized as one of the most invasive insects on the world $[10,19,20]$, has been introduced in

61 numerous ecosystems worldwide [19, 21-29]. As an invasive species, it has caused adverse 62 impacts on the wine industry [30-32] and as a household invader during winter. It is an effective generalist predator of numerous hemipteran pests [33], with higher fertility and fecundity than competitive ladybeetle species [27, 34-35], significant adaptability and resilience [36], and has a dominant role as an intraguild predator [37-41]. These attributes suit the multicolored Asian 
67 diversity of natural enemies in certain regions, especially ladybeetles, [33] through exploitative competition and intraguild predation [34, 39, 43-44].

The twelve spotted ladybeetle, Coleomegilla maculata (DeGeer) (Col., Coccinellidae), is one of the sympatric competitors of $H$. axyridis, in Nearctic apple orchards [45] as well as in other

71 agricultural ecosystems, such as potato [46-47] and sweet corn [24]. This ladybeetle, is an

72 indigenous generalist predator in North America, and an important biocontrol agent in various crops $[45,47-49]$ that also participates in IGP with other coccinellids. Thus, both coccinellids, $C$. maculata and H. axyridis, frequently engage in mutual IGP [50].

Although IGP has an important adaptive value for the intraguild predator, it also involves certain risks, such as the risk of injuries or an increase of exposure to pesticides [51]. Moreover,

77 it has been proposed that $75 \%$ of the biodiversity can be concentrated in agricultural landscapes and thus, species are exposed to pesticides used for plant protection [52]. Despite

79 of this, very few studies have addressed the impact of pesticides on IGP $[51,53]$. Besides, it 80 remains difficult to establish how pesticide applications may affect success of invasive species 81 using IGP as competitive arm.

82 Previous research has shown that novaluron (Rimon ${ }^{\circledR}$ EC 10), a reduced-risk insecticide (RRI) and chitin synthesis inhibitor [54], used to control the codling moth, Cydia pomonella (L.) (Lep.,

84 Tortricidae), a major pest in Quebec apple orchards [55], has differential lethal and sublethal

85 effects on $H$. axyridis compared to C. maculata, the multicolored Asian ladybeetle being drastically more susceptible to the insecticide than its indigenous intraguild competitor [56-57]. 
by several mechanisms, such as sequestration, excretion and detoxification [58], and these can determine differences in susceptibilities to pesticides among natural enemies [59].

The aims of this study are 1) to compare the adaptive value of mutual IGP, for the two coccinellids, the invasive and the native species, when the IGP prey faced exposition to an insecticide used in the invaded area; and 2) to investigate if the effect of the exposition on the adaptive value of IGP can disappear over time through neutralisation of the insecticide by the intraguild prey, the least susceptible species (the indigenous) to novaluron. We hypothesize that the adaptive value of IGP, for the indigenous tolerant twelve spotted ladybeetle, will be maintained in the presence of the insecticide, whereas it will be greatly reduced for the susceptible invasive Asian ladybeetle. We also hypothesize that the adaptive value of IGP for the susceptible invasive species will be recovered, after a period, when the native IG prey will have neutralized the insecticide.

\section{Materials and methods}

\section{Insects} collected in the field in Quebec in 2016 at Sainte-Agathe $\left(46^{\circ} 23^{\prime} 0.3^{\prime \prime} \mathrm{N}\right.$ and $\left.71^{\circ} 24^{\prime} 33.5^{\prime \prime} \mathrm{W}\right)$. New individuals coming from the field were added every year to the rearings. These were in a

105 growth chamber at $24^{\circ} \mathrm{C}, 16 \mathrm{~L}: 8 \mathrm{D}$, and $70 \% \mathrm{RH}$ at Laboratoire de Lutte Biologique from the 106 Université du Québec à Montréal. Insects were provided with pollen, sweetened water solution 
107 (10\% sugar), and green peach aphids, Myzus persicae (Sulz.) (Hem., Aphididae), reared on 108 potato plants, Solanum tuberosum L.

$112 \mathrm{ha}^{-1}$, most used by apple growers in Quebec, were considered in the concentration for

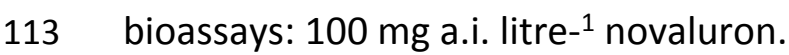

\section{4} deposit) and euthanized by freezing to avoid cannibalism. Also thawed for $3 \mathrm{~min}$ at $20^{\circ} \mathrm{C}$ before 125 the bioassay) (Fig 1). Each experimental unit was replicated 17 times. Intraguild predators and 126

\section{Bioassays}

A first bioassay was intended to assess the effect of novaluron on intraguild predation by both coccinellid species on the other one. A second bioassay was performed to explore neutralisation of pesticide by C. maculata as an intraguild prey, and its effect on $H$. axyridis as the intraguild predator.

\section{Effect of the insecticide on intraguild predation}

Experimental units consisted in a newly molted second instar C. maculata or H. axyridis larvae (intraguild predator), individually weighted, and placed in $5 \mathrm{~cm}$ Petri dishes with 5 first instar larvae from the opposite ladybeetle species (intraguild prey), previously treated with novaluron or water with a Potter Tower $(1 \mathrm{ml}$ solution and $2 \mathrm{mg} \mathrm{cm}-2$ aqueous insecticide prey were left together during $24 \mathrm{~h}$. Leftovers of intraguild prey were noted and removed 
127 afterwards. After that, intraguild predators were fed with $M$. persicae aphids daily until the

128 adult stage. Mortality and stage of development were noted on a daily basis. Once the 129 individuals became adults, they were weighted again.

131 Figure 1. Experimental design used to assess the effect of novaluron on IGP. Each

132 experimental unit consisted of a second instar larva (intraguild predator) placed with five 1st

133 instar newly hatched larvae from the opposite coccinellid species. Each experimental unit was 134 replicated 17 times. and its effect on the invasive intraguild predator $\boldsymbol{H}$. axyridis.

a) T0: $1^{\text {st }}$ instar larvae of the indigenous ladybeetle or aphids, insecticide or water treated, and immediately euthanized,

b) T-24h: first instar larvae of the indigenous ladybeetle or aphids, insecticide or water treated and euthanized $24 \mathrm{~h}$ after,

c) T-Molt: first instar larvae of the indigenous ladybeetle or aphids, insecticide or water treated and euthanized after molt to $2^{\text {nd }}$ instar.

46 Additionally, three treatments were associated to each of the treatments mentioned above; 
1- XG-Water: Aphids treated with water, representing optimal extraguild prey, and offered ad libitum to intraguild predators,

2- IG-Water: $1^{\text {st }}$ instar larvae of the indigenous LB, treated with water, and

3- IG-Insecticide: $1^{\text {st }}$ instar larvae of the indigenous LB, treated with the insecticide (novaluron).

A Potter tower was used to treat larvae $\left(1 \mathrm{ml}\right.$ solution and $2 \mathrm{mg} / \mathrm{cm}^{2}$ aqueous insecticide deposit). All preys were weighted prior to freezing. Experimental units were replicated 17 times and consisted of five C. maculata larvae, thawed during $3 \mathrm{~min}$ at $20^{\circ} \mathrm{C}$, and placed in a $5 \mathrm{~cm}$ Petri dish with a newly molted $3^{\text {rd }}$ instar $H$. axyridis larva, previously starved during $24 \mathrm{~h}$. Third instar larvae were used as intraguild predators in this bioassay, in order to encourage IGP by reducing the prey/predator body mass ratio. Intraguild predators were in contact with extraguild and intraguild prey during $24 \mathrm{~h}$. Intraguild and extraguild prey leftovers were noted and removed afterwards and intraguild predators were fed with fresh green peach aphids daily until reaching the adult stage. Mortality was assessed daily and $H$. axyridis individuals were weighted after reaching adult stage.

\section{Calculations and statistical analyses}

Differences in frequencies of mortality in both bioassays were evaluated with a Chi $^{2}$ test $(\alpha=$ 0.05) [60], and pairwise comparisons, with Bonferroni corrections of the $p$ value, were performed to detect differences among treatments [61]. Results are presented as mortality 
percentages. Survival was analysed by means of Survival Analysis and a Proportional Hazard model to detect differences among groups [62].

Voracity of the intraguild predator was calculated by assessing $1^{\text {st }}$ instar larvae (intraguild prey) leftovers after $24 \mathrm{~h}$ of IGP. Mass of consumed prey $(\mathrm{mg})$ was estimated from percentages of leftover prey and weight of prey before freezing (for the neutralisation of the insecticide by the

171 intraguild prey section). Weight increase of intraguild predators until the adult stage was

172 calculated subtracting second or third instar larvae initial weight from adult weight (g). This 173 variable, as well as voracity, were analysed with the independent samples Student's t test $(\alpha=$ $1740.05)$ to investigate the effect of novaluron on both ladybeetle species and with Analysis of 175 Variance and the Tukey test or the non-parametric Wilcoxon test and the Steel-Dwass All Pairs 176 test $(\alpha=0.05)$ (SAS Institute, 2015) to detect differences among treatments in the case of the

177 effect of insecticide neutralisation by intraguild prey on $H$. axyridis, since data did not always 178 meet the normality assumption. Time of development of $C$. maculata as the intraguild predator, 179 in the first bioassay, was examined with the independent samples Student's $t$ test $(\alpha=0.05)$ 180 [59] and time of development of $H$. axyridis in the second bioassay was investigated with the 181 Wilcoxon test $(\alpha=0.05)$ [63]. JMP software v.12.1 (SAS Institute, Cary, NC) was used to perform 182 all statistical analyses. 


\section{Results}

\section{Effect of the insecticide on intraguild predation}

\section{Voracity of intraguild predators}

There were no differences in voracity between the insecticide treatment and the control, $t_{(30.99)}$

$=1.469, p=0.152$ for the indigenous ladybeetle. A different trend was found for $H$. axyridis.

Less prey was ingested in the insecticide treatment than in the control $t_{(29.37)}=-2.283, p=$

Table 1. Voracity of intraguild predators after $24 \mathrm{~h}$ feeding on intraguild prey treated with

water or insecticide. Comparisons within lines. Student t test $(p<0.05)$

\begin{tabular}{|l|c|c|}
\cline { 2 - 3 } \multicolumn{1}{c|}{} & \multicolumn{2}{c|}{ Intraguild prey consumed (\% \pm SE) } \\
\cline { 2 - 3 } \multicolumn{1}{c|}{} & Control & Insecticide \\
\hline Indigenous ladybeetle & $42.81 \pm 7.27 \mathrm{~A}$ & $58.06 \pm 7.41 \mathrm{~A}$ \\
\hline Invasive ladybeetle & $61.56 \pm 7.33 \mathrm{a}$ & $40.00 \pm 5.96 \mathrm{~b}$ \\
\hline
\end{tabular}

\section{Mortality-survival of intraguild predators}

After feeding on intraguild prey (first instar invasive ladybeetle) treated with novaluron,

$=0.013, p=0.9086$ (Fig 2-a). Surviving individuals molted normally and completed development

197 until the adult stage. In the case of the invader $H$. axyridis, all larvae died after IGP in the 198 novaluron treatment, which mortality was significantly higher than the control, $X^{2}{ }_{(1)}=15.245, p$ $199<0.0001$ (Fig 2-b). Survival analysis for intraguild predators, preying on intraguild prey treated 
201 time, $X^{2}{ }_{(1)}=12.731, p=0.0004$. All $H$. axyridis larvae died between the first and fifth day

202 following IGP and none of the predators were able to molt before death, whereas $70 \%$ of

203 indigenous C. maculata individuals reached the adult stage (Fig 2-d).

Figure 2. a) Mortality of the indigenous ladybeetle as the intraguild predator, b) Mortality of the

207 (intraguild preys) to water or insecticide-treated preys. Chi $\left.{ }^{2}(p<0.05), c\right)$ Survival and time of

208 death of intraguild predators after ingestion of intraguild prey treated with water and d) treated with the insecticide. Kaplan-Meier survival curves $(p<0.05)$.

\section{Time of development and weight increase (indigenous ladybeetle)}

212 Since all $H$. axyridis individuals in the insecticide treatment died at the second larval instar,

213 results of time of development and weight increase were obtained only for $C$. maculata in this

214 treatment. Time of development until adult stage, after IGP, for the twelve spotted ladybeetle,

215 in the insecticide treatment, was not different than the control $t_{(21)}=0.622, p=0.541$ (Fig 3-a).

216 Weight increase was not statistically different between the control and novaluron treatments, $t_{(17.97)}=2.08, p=0.0521$ (Fig. 3-b). 
220

221

222

223

224

225

226

227

228

229

230

231

232

233

234

235

Figure 3. a) Time of development (days $+\mathrm{SE})$ and b) weight increase ( $\mathrm{mg} \pm \mathrm{SE}$ ) of the indigenous ladybeetle, from 2 nd instar larvae until adult stage, after $24 \mathrm{~h}$ feeding on intraguild prey treated with water or insecticide. Student t test $(p<0.05)$

\section{Neutralisation of the insecticide by the indigenous intraguild prey and}

\section{its effect on the invasive intraguild predator.}

\section{Voracity of the invasive ladybeetle}

Harmonia axyridis consumed similar proportions of intraguild prey treated with water in the three treatments: $X^{2}{ }_{(1)}=5.004, p=0.082$. When comparing voracity of $H$. axyridis preying upon C. maculata, treated with novaluron, among the three treatments, there were slightly more intraguild preys consumed in the TO treatment compared to the other treatments. However the T-24h treatment was not different from T-Molt: $F_{(2)}=11.12, p=0.0002$ (Table 2.).

Table 2. Voracity of $\boldsymbol{H}$. axyridis after $24 \mathrm{~h}$ preying upon extraguild (XG) and intraguild (IG) prey treated with insecticide or water. Comparisons are done within lines. ANOVA or Wilcoxon test $(p<0.05)$.

\begin{tabular}{|l|c|c|c|}
\cline { 2 - 4 } \multicolumn{1}{c|}{} & \multicolumn{3}{c|}{ Consumed prey (mg \pm SE) } \\
\hline Treatment & T0 & T-24h & T-Molt \\
\hline XG-Water & $7.37 \pm 1.95$ a & $9.76 \pm 1.20$ a & $7.79 \pm 0.93$ a \\
\hline IG-Water & $0.77 \pm 0,10$ A & $0.92 \pm 0.17$ A & $1.16 \pm 0.18$ A \\
\hline IG-Insecticide & $1.07 \pm 0.05$ A $^{\prime}$ & $0.40 \pm 0.04$ B' & $0.69 \pm 0.16$ B' $^{\prime}$ \\
\hline
\end{tabular}



and T-Molt), when consuming water-treated extraguild prey, this is green peach aphids: $X^{2}{ }_{(2)}=$ predators consumed $C$. maculata first instar larvae treated with water, $X^{2}{ }_{(2)}=0.857, p=0.652$. However, when comparing mortality frequencies of the invasive ladybeetle after feeding on the indigenous ladybeetle treated with novaluron, the T-Molt treatment showed significantly less mortality $X^{2}{ }_{(1)}=23.221, p<0.0001 ;$ T-24h vs T-Molt: $X^{2}{ }_{(1)}=13.55, p=0.0002 ;$ T0 vs T-Molt: $X^{2}{ }_{(1)}$

$244=13.38, p=0.0003$ (Bonferroni $\alpha=0.025$ ). Moreover, it was found that intraguild predators 245 feeding on prey treated with novaluron in treatments T0 and T-24h had a higher mortality than their controls of extraguild prey and intraguild prey treated with water $\left(X^{2}{ }_{(1)}=20.285, p<\right.$ 0.0001; T0-IG-Insecticide vs T0-XG-Water: $X^{2}{ }_{(1)}=14.4, p=0.0001 ;$ T0-IG-Insecticide vs T0-IGWater: $X^{2}{ }_{(1)}=17.14, p<0.0001$ and $X^{2}{ }_{(1)}=19.217, p<0.0001 ;$ T-24h-IG-Insecticide vs T-24h-XGWater: $X^{2}{ }_{(1)}=16.22, p<0.0001 ;$ T-24h-IG-Insecticide vs T-24h-IG-Water: $X^{2}{ }_{(1)}=13.55, p=$ 0.0002 , Bonferroni $\alpha=0.017$ respectively ) (Fig 4-a). treatments, after IGP on prey treated with novaluron, showed that $70 \%$ of individuals in the TMolt treatment became adults, whereas all individuals died in treatments T0 and T-24h before

254 nine days (Fig 4-b). The Proportional Hazard Model indicated that this difference was 255 significant: $X^{2}{ }_{(2)}=19.91, p<0.0001$. Moreover, individuals in TO/IG-Insecticide were \pm 15 times more prone to die than individuals in T-Molt/IG-Insecticide $(p<0.0001)$. Similarly, larvae in T- 
257

258

259

260

261

262

263

264

265

266

267

268

269

270

271

272

273

274

275

24h/IG-Insecticide had \pm 11 times probabilities of death than larvae in T-Molt-IG-Insecticide $(p=$ $0.0002)$.

Figure 4. a) Mortality of the invasive ladybeetle (intraguild predator), after $24 \mathrm{~h}$ exposure of $3^{\text {rd }}$ instar larvae to water or insecticide-treated intraguild preys, in treatments of neutralisation of the insecticide by the intraguild prey $\left(\mathrm{Chi}^{2}(\alpha=0.05)\right)$ and b) survival of intraguild predators after ingestion of intraguild prey treated with insecticide in three neutralisation treatments. Kaplan-Meier survival curves $(p<0.05)$. T0: $1^{\text {st }}$ instar larvae of the indigenous ladybeetle or aphids, insecticide or water treated, and immediately euthanized; T-24h: first instar larvae of the indigenous ladybeetle or aphids, insecticide or water treated and euthanized $24 \mathrm{~h}$ after; TMolt: first instar larvae of the indigenous ladybeetle or aphids, insecticide or water treated and euthanized after molt to $2^{\text {nd }}$ instar; XG-Water: Aphids treated with water; IG-Water: $1^{\text {st }}$ instar larvae of the indigenous ladybeetle, treated with water; IG-Insecticide: $1^{\text {st }}$ instar larvae of the indigenous ladybeetle, treated with insecticide (novaluron).

\section{Time of development and weight increase of the invasive ladybeetle}

Data from T0 and T-24h with treated intraguild preys are absent, since no individual reached the adult stage. No significant differences among treatments were found in the time of development after IGP, from third instar to adult stage: $X^{2}{ }_{(6)}=1.16, p=0.98$ (Fig 5-a). 
276 Similarly to time of development, no significant differences were detected in weight increase

277 among treatments: $X^{2}{ }_{(6)}=11.93, p=0.064$ (Fig 5-b).

279 Figure 5. a) Time of development (days) of the invasive $H$. axyridis, from $3^{\text {rd }}$ instar larvae until

280 adult stage, after $24 \mathrm{~h}$ feeding on intraguild prey treated with water or insecticide and

281 extraguild prey; b) Weight increase (mg) of $H$. axyridis from third instar larvae until adult stage,

282 after $24 \mathrm{~h}$ feeding on intraguild prey treated with insecticide or water and extraguild prey.

283 Wilcoxon test $(\alpha=0.05)$. T0: $1^{\text {st }}$ instar larvae of the indigenous ladybeetle or aphids, insecticide

284 or water treated, and immediately euthanized; T-24h: first instar larvae of the indigenous

285 ladybeetle or aphids, insecticide or water treated and euthanized $24 \mathrm{~h}$ after; T-Molt: first instar

286 larvae of the indigenous ladybeetle or aphids, insecticide or water treated and euthanized after

287 molt to $2^{\text {nd }}$ instar; XG-Water: Aphids treated with water; IG-Water: $1^{\text {st }}$ instar larvae of the

288 indigenous ladybeetle, treated with water; IG-Insecticide: $1^{\text {st }}$ instar larvae of the indigenous

289 ladybeetle, treated with insecticide (novaluron).

\section{Discussion}

291 Effect of the insecticide on the adaptive value of IGP for the invasive

\section{2 and the indigenous predators}

293 Our results support our $1^{\text {st }}$ hypothesis that the adaptive value of IGP, for the invasive 294 multicolored Asian ladybeetle, is completely lost when preying on intraguild prey treated with 
295 the insecticide. Furthermore, it is in accordance with previous research, confirming a 296 differential susceptibility of both predator species to the reduced risk insecticide novaluron [56-

297 57]. At the opposite, after preying on intraguild insecticide-treated prey during $24 \mathrm{~h}$, the 298 adaptive value of IGP was maintained for the tolerant indigenous twelve spotted ladybeetle. 299 Survival success was not different than survival in absence of the insecticide and neither voracity and weight increase, nor developmental time, were altered.

301 IGP is particularly advantageous for the adaptive value of intraguild predators, by removing competitors and potential predators, gaining energy and nutrition and consequently surviving, developing and reproducing when extraguild prey densities are low [16]. For instance, pollen is consumed by coccinellids at the beginning of the growing season in temperate regions, when prey densities are low, but in general it does not allow maturation of ovaries, therefore IGP is beneficial at that period [39]. Additionally, by the end of the season, IGP can help immature stages of predators to reach the adult stage, the overwintering stage in ladybeetles [64, 65]. However, our results show that an insecticide can drastically alter the outcome of IGP and even, completely cancel out its adaptive value for the intraguild predator. this predator. The adaptive value is completely lost and IGP becomes a highly risky behaviour,

314 which it is not the case for the indigenous $C$. maculata. Thus, consequences of IGP between 315 both, the indigenous and the invasive ladybeetles are reversed by the insecticide. 
At a population level, a shift in the dominance of species on the coccinellid assemblage might

67] or habitats with little structure [68-69]. In this context, an insecticide might reduce

other natural enemies. Declines of natural enemies of Hemipterans, especially indigenous lady beetles in several regions where the multicolored Asian ladybeetle has established, have been attributed to interspecific competition for resources and the strong intraguild predation abilities of this invasive species [13]. Yet, the outcome of these repercussions in communities

\section{predator}

Our second hypothesis stating that the adaptive value of IGP, lost as a consequence of intraguild prey contamination by an insecticide, is recovered over time, is also supported by the results. This might be linked to neutralisation of the compound by the intraguild prey. Survival of the intraguild predator is significantly higher after feeding on contaminated intraguild prey having molted to the next stage compared to intraguild prey more recently treated. Results of voracity show that this finding is not due to a lower consumption of treated intraguild prey compared to the T-24h treatment. Weight increase of the intraguild predator, after predation on treated intraguild prey does not differ from weight increase after consumption of extraguild 
337 The same trend is observed for the time of development of the intraguild predator. Therefore,

338 benefits of intraguild predation are recovered over time. $[49,70]$. This hypothesis has already been mentioned in previous articles [56-57] but must be

Several phenomena may explain predator susceptibility to insecticides, among these, penetration, absorption and neutralisation may be significant. Penetration through the cuticle and rate of absorption of the compound in the arthropod body following topical contact or gut wall after ingestion may differ among species [54, 59]. Neutralisation can also be different among species. Toxic compounds can be neutralized by insects through sequestration (storage of compounds in an unaltered form), increased rates of excretion (removal of the toxic substance without altering its integrity) and detoxification (biochemical transformation of the compound in a way that it won't harm the insect) [57]. Although we do not know how these mechanisms are involved, we formulate three hypotheses that might explain the recovery of the adaptive value of IGP by the intraguild predator over time: a) low penetration of the insecticide through the cuticle/gut wall of the intraguild prey, which is shed during the next molt or/and b) physiological neutralisation of the insecticide by the intraguild prey, occurring over time, c) elimination via feces. Thus, the outcome of IGP for the intraguild predator depends on the time that has passed, after exposure of the intraguild prey to the insecticide, specifically the time that is required for the intraguild prey to shed the contaminated cuticle or/and neutralise the insecticide to levels that will not harm the predator. The ability of $C$. maculata to neutralize the insecticide could be explained by a preadaptation to deal with toxic secondary plant compounds, since this species seems to be more phytophagous than $H$. axyridis tested in future research. 
367 (Neur., Chrysopidae), the predatory plant bug Deraeocoris brevis (Uhler) (Hem., Miridae), the 368 ladybeetle Hippodamia convergens Guérin-Méneville (Col., Coccinellidae), and the mite competitors, which changes the dynamics of the guild and the frequency of encounters for IGP.

The present investigation suggests that pesticide regime should be taken in consideration when assessing the ecological impact of invasive species in a new environment. Studies of lethal and sublethal effects of compounds used in the environment involved, as well as effects on behaviour of invaders and intraguild interactions at a population level, should be envisaged. Our research also highlights the side effects of reduced-risk insecticides (novaluron) on beneficial organisms and potentially on invasive species and their ecological consequences.

Novaluron is a wide spectrum insecticide highly toxic for the Asian ladybeetle [56-57], as well as for other natural enemies found orchards, such as the lacewing Chrysoperla carnea (Stephens) predators Galendromus occidentalis (Nesbitt) [71] and Neoseiulus fallacis (Garman) (Aca., Phytoseiidae) [72].

However, certain natural enemies are less susceptible to it, as it is the case of the twelve spotted ladybeetle [56-57] and the parasitoid Aphelinus mali (Hald.) (Hym., Aphelinidae) [71]. Accordingly, as mentioned in 4.1., impact of IGP on coccinellid assemblages, as well as on aphidophagous guilds facing pesticides will be determined by the variability of susceptibilities among guild members as well as neutralisation of toxic compounds by intraguild preys.

Moreover, insecticides can modify the composition of guilds, altering occurrences of Our results suggest that direct and indirect effects of insecticide treatments in agroecosystems 
379 are likely to have important impacts on ecosystem services of guilds, particularly on biocontrol

380 by interfering with IGP.

381 The present study highlights the impact of an insecticide on an adaptive behaviour for a top

382 predator, which is one of the key factors associated to the invasive status of the multicolored

383 Asian ladybeetle worldwide. At an ecological level, our findings show that an insecticide might

384 alter not only guild composition but also disturb intraguild interactions and consequently alter 385 cascade effects in trophic systems.

386 Acknowledgements

387 We thank Jill Vandermeerschen for her advice with statistics, Franz Vanoosthuyse for technical

388 support, and Chloé Savoie, Maryse Pelletier, Mathieu Lemieux, and Marie Elen Dupuis for 389 assisting with ladybeetle bioassays.

390 References

391 1. Mooney HA, Cleland EE. The evolutionary impact of invasive species. Proc Natl Acad Sci USA. 2001; 98(10): 5446-5451.

2. Strayer DL, Eviner VT, Jeschke JM, Pace ML. Understanding the long-term effects of species invasions. Trends Ecol Evol. 2006; 21(11): 645-651.

3. Pejchar L, Mooney HA. Invasive species, ecosystem services and human well-being. Trends Ecol Evol. 2009; 24(9): 497-504. 
397

398

399

400

401

402

403

404

405

406

407

408

409

410

411

412

413

414

415

4. Vilà M, Basnou C, Pyšek P, Josefsson M, Genovesi, P, Gollasch, S, Roy D, et al. How well do we understand the impacts of alien species on ecosystem services? A pan-European, cross-taxa assessment. Front Ecol Environ. 2010; 8(3): 135-144.

5. Walsh JR, Carpenter SR, Vander Zanden MJ. Invasive species triggers a massive loss of ecosystem services through a trophic cascade. Proc Natl Acad Sci USA. 2016; 113(15): 40814085.

6. Kolar CS, Lodge DM. Progress in invasion biology: predicting invaders. Trends Ecol Evol. 2001; 16(4): 199-204.

7. Sakai A K, Allendorf FW, Holt JS, Lodge DM, Molofsky J, With KA, Ellstrand NC, et al. The population biology of invasive species. Annu Rev Ecol Syst. 2001; 32(1): 305-332.

8. Crowder DW, Snyder WE. Eating their way to the top? Mechanisms underlying the success of invasive insect generalist predators. Biol Invasions. 2010; 12(9): 2857-2876.

9. Evans EW, Soares AO, Yasuda H. Invasions by ladybugs, ladybirds, and other predatory beetles. BioControl. 2011; 56(4): 597-611.

10. Snyder WE, Evans EW. Ecological effects of invasive arthropod generalist predators. Annu Rev Ecol Syst S. 2006; 37: 95-122.

11. Eubanks MD, Blackwell SA, Parrish CJ, Delamar ZD, Hull-Sanders H. Intraguild predation of beneficial arthropods by red imported fire ants in cotton. Environ Entomol. 2002; 31(6): 1168-1174. 
12. Michaud JP. Coccinellids in biological control. In: Hodek I, Honek A, Van Emden HF, editors. Ecology and Behaviour of the Ladybird Beetles (Coccinellidae). John Wiley \& Sons. 2012. pp. 488-519.

13. Pell JK, Baverstock J, Roy HE, Ware RL, Majerus MEN. Intraguild predation involving Harmonia axyridis : a review of current knowledge and future perspectives. In: Roy HE, Wajnberg E, editors. From Biological Control to Invasion: the Ladybird Harmonia axyridis as a Model Species. 2008. Springer Netherlands. pp. 147-168.

14. Snyder WE, Clevenger G, Eigenbrode SD. Intraguild predation and successful invasion by introduced ladybird beetles. Oecologia. 2004, 140(4): 559-565.

15. Polis GA, Holt RD. Intraguild Predation-The Dynamics of Complex Trophic Interactions. Trends Ecol Evol. 1992; 7(5): 151-154.

16. Polis GA, Myers CA, Holt RD. The Ecology and Evolution of Intraguild Predation - Potential Competitors That Eat Each Other. Annu Rev Ecol Syst. 1989; 20: 297-330.

17. Müller CB, Brodeur J. Intraguild predation in biological control and conservation biology. Biol Control. 2002; 25(3): 216-223.

18. Rosenheim JA, Kaya HK, Ehler LE, Marois JJ, Jaffee BA. Intraguild Predation Among Biological-Control Agents: Theory and Evidence. Biol Control. 1995; 5(3): 303-335.

19. Brown PM, Thomas CE, Lombaert E, Jeffries DL, Estoup A, Handley L-JL. The global spread of Harmonia axyridis (Coleoptera: Coccinellidae): distribution, dispersal and routes of invasion. Biocontrol. 2011; 56(4): 623-641. 
436

437

438

439

440

441

442

443

444

445

446

447

448

449

450

451

452

453

454

20. Vandereycken A, Durieux D, Joie É, Haubruge É, Verheggen F. Habitat diversity of the Multicolored Asian ladybeetle Harmonia axyridis Pallas (Coleoptera: Coccinellidae) in agricultural and arboreal ecosystems: a review. Biotechnologie, Agronomie, Société et Environnement. $2012 ; 16(4)$ : 553-563.

21. Coderre D, Lucas É, Gagné I. The occurrence of Harmonia axyridis (Pallas) (Coleoptera: Coccinelidae) in Canada. Can Entomol. 1995; 127(4) : 609-611.

22. Coutanceau J-P. Harmonia axyridis (Pallas, 1773): une coccinelle asiatique introduite, acclimatée et en extension en France. Bulletin de la Société entomologique de France. $2006 ; 111(3): 395-401$.

23. Gordon RD. The Coccinellidae (Coleoptera) of America north of Mexico. J New York Entomol S. $1985 ; 93(1)$.

24. Lucas E, Vincent C, Labrie G, Chouinard G, Fournier F, Pelletier F, Lafontaine P, et al. The multicolored Asian ladybeetle Harmonia axyridis (Coleoptera: Coccinellidae) in Quebec agroecosystems ten years after its arrival. Eur J Entomol. 2007; 104(4): 737-743.

25. Nedvěd O, Háva J, Kulíková D. Record of the invasive alien ladybird Harmonia axyridis (Coleoptera, Coccinellidae) from Kenya. ZooKeys. 2011; 106: 77-81.

26. Roy HE, Brown PMJ, Adriaens T, Berkvens N, Borges I, Clusella-Trullas S, et al. The harlequin ladybird, Harmonia axyridis: global perspectives on invasion history and ecology. Biol Invasions. 2016; 18(4): 997-1044. 
27. Soares AO, Borges I, Borges PA, Labrie G, Lucas E. Harmonia axyridis: What will stop the invader? BioControl. 2008; 53(1): 127-145.

28. Stals R, Prinsloo G. Discovery of an alien invasive, predatory insect in South Africa: the multicoloured Asian ladybird beetle, Harmonia axyridis (Pallas)(Coleoptera: Coccinellidae). S Afr J Sci. 2007; 103(3-4): 123-126.

29. Tedders W, Schaefer P. Release and establishment of Harmonia axyridis (Coleoptera: Coccinellidae) in the southeastern United States. Entomol News. 1994; 105(4): 228-243.

30. Ker KW, Pickering GJ, Dris R. Biology and control of the novel grapevine pest-The multicolored Asian lady beetle Harmonia axyridis. WFL Publisher Helsinki, Finland; 2005.

31. Linder C, Lorenzini F, Kehrli P. Potential impact of processed Harmonia axyridis on the taste of 'Chasselas' and 'Pinot noir'wines. Vitis. 2009; 48(2): 101-102.

32. Pickering G, Spink M, Kotseridis $Y$, Brindle I, Sears M, Inglis D. The influence of Harmonia axyridis morbidity on 2-Isopropyl-3-methoxy-pyrazine in 'Cabernet Sauvignon'wine. Vitis. 2008; 47(4): 227-230.

33. Koch RL, Galvan TL. Bad side of a good beetle: the North American experience with Harmonia axyridis. BioControl. 2008; 53(1): 23-35.

34. Michaud JP. Invasion of the Florida Citrus Ecosystem by Harmonia axyridis (Coleoptera: Coccinellidae) and Asymmetric Competition with a Native Species, Cycloneda sanguinea. Environ Entomol. 2002; 31(5): 827-835. 
474

475

476

477

478

479

480

481

482

483

484

485

486

487

488

489

490

491
35. Santos LDCD, Santos-Cividanes TMD, Cividanes FJ, Matos STSD. Biological aspects of Harmonia axyridis in comparison with Cycloneda sanguinea and Hippodamia convergens. Pesquisa Agropecuária Brasileira. 2013; 48(11): 1419-1425.

36. Brown PMJ, Adriaens T, Bathon H, Cuppen J, Goldarazena A, Hägg T, et al. Harmonia axyridis in Europe: spread and distribution of a non-native coccinellid. BioControl. 2008; 53(1): 521.

37. Brown PMJ, Ingels B, Wheatley A, Rhule EL, De Clercq P, Van Leeuwen $T$, et al. Intraguild predation by Harmonia axyridis (Coleoptera: Coccinellidae) on native insects in Europe: molecular detection from field samples. Entomol Sci. 2015; 18(1): 130-133.

38. Lucas E. Intraguild predation among aphidophagous predators. Eur J Entomol. 2005; 102: 351-364.

39. Lucas E. Intraguild interactions. In: Hodek I, Van Emden HF, Honek A, editors. Ecology and Behaviour of the Ladybird beetles (Coccinellidae). John Wiley \& Sons; 2012. pp. 343-374.

40. Mirande L, Desneux N, Haramboure M, Schneider M. Intraguild predation between an exotic and a native coccinellid in Argentina: the role of prey density. J Pest Sci. 2015; 88(1): $155-162$.

41. Ware R, Yguel B, Majerus M. Effects of competition, cannibalism and intra-guild predation on larval development of the European coccinellid Adalia bipunctata and the invasive species Harmonia axyridis. Ecol Entomol. 2009; 34(1): 12-19. 
42. Hautier L, San Martin G, Callier P, de Biseau J-C, Grégoire J-C. Alkaloids provide evidence of intraguild predation on native coccinellids by Harmonia axyridis in the field. Biol Invasions. 2011; 13(8): 1805-1814.

43. Hautier L, Grégoire J-C, de Schauwers J, San Martin G, Callier P, Jansen J-P, et al. Intraguild predation by Harmonia axyridis on coccinellids revealed by exogenous alkaloid sequestration. Chemoecology. 2008; 18(3): 191-196.

44. Roy $\mathrm{H}$, Wajnberg E. From biological control to invasion: the ladybird Harmonia axyridis as a model species. BioControl. 2008; 53(1): 1-4.

45. Fréchette B, Cormier D, Chouinard G, Vanoosthuyse F, Lucas E. Apple aphid, Aphis spp. (Hemiptera: Aphididae), and predator populations in an apple orchard at the non-bearing stage: The impact of ground cover and cultivar. Eur J Entomol. 2008; 105: 521-529.

46. Kabaluk J, Vernon R, Henderson D. Population development of the green peach aphid and beneficial insects in potato fields in British Columbia. Can Entomol. 2006; 138(5): 647-660.

47. Lucas É, Giroux S, Demougeot S, Duchesne RM, Coderre D. Compatibility of a natural enemy, Coleomegilla maculata lengi (Col., Coccinellidae) and four insecticides used against the Colorado potato beetle (Col., Chrysomelidae). J Appl Entomol. 2004; 128(3): 233-239.

48. Cottrell TE, Yeargan KV. Intraguild predation between an introduced lady beetle, Harmonia axyridis (Coleoptera: Coccinellidae), and a native lady beetle, Coleomegilla maculata (Coleoptera: Coccinellidae). J Kansas Entomol Soc. 1998; 71(2): 159-163. 
49. Lundgren JG, Razzak AA, Wiedenmann RN. Population responses and food consumption by predators Coleomegilla maculata and Harmonia axyridis (Coleoptera: Coccinellidae) during anthesis in an Illinois cornfield. Environ Entomol. 2004; 33(4): 958-963.

50. Gagnon A-È, Heimpel GE, Brodeur J. The ubiquity of intraguild predation among predatory arthropods. PLoS One. 2011; 6(11): e28061.

51. Provost C, Coderre D, Lucas É, Bostanian NJ. Impact of Lambda-cyhalothrin on Intraguild Predation Among Three Mite Predators. Environ Entomol. 2003; 32(2): 256-263.

52. Lucas E, Maisonhaute J-E. Paysage et services écosystémiques, une nouvelle dimension dans la lutte aux insectes nuisibles. In: Ruiz J, Domon G, editors. Agriculture et paysage, Aménager autrement les territoires ruraux: Les Presses de l'Université de Montréal. 2014 ; pp. 175-196.

53. Provost C, Coderre D, Lucas E, Bostanian NJ. Impact d'une dose subletale de lambdacyhalothrine sur les predateurs intraguildes d'acariens phytophages en verger de pommiers. Phytoprotection. 2003; 84: 105-113.

54. Cutler GC, Scott-Dupree CD. Novaluron: Prospects and Limitations in Insect Pest Management. Pest Technology. 2007; 1(1): 38-46.

55. Cormier D, Chouinard G, Pelletier F, Vanoosthuyse F, Joannin R. An interactive model to predict codling moth development and insecticide application effectiveness. IOBC-WPRS Bulletin. 2016; 112: 65-70. 
531 56. Cabrera P, Cormier D, Lucas É. Differential Sensitivity of an Invasive and an Indigenous Ladybeetle to Two Reduced-Risk Insecticides. J Appl Entomol. 2017; 141(9): 690-701.

57. Cabrera P, Cormier D, Lucas É. Sublethal Effects of Two Reduced-risk Insecticides: When the invasive ladybeetle is drastically affected whereas the indigenous not. J Pest Sci. 2018; 91(3). pp 1153-1164

58. Dowd PF, Smith MC, Sparks TC. Detoxification of plant toxins by insects. Insect Biochem. 1983; 13(5): 453-468. Sons; 1990.

60. Sokal R, Rohlf J. Biometry : the principles and practice of statistics in biological research. Rohlf FJ, editor. New York: New York W. H. Freeman; 1995. Available from: http://www.biostathandbook.com/chiind.html. Springer; 2012. 
548

549

550

551

552

553

554

555

556

557

558

559

560

561

562

563

564

565

566

567
64. Labrie G, Coderre D, Lucas E. Overwintering strategy of multicolored Asian lady beetle (Coleoptera: Coccinellidae): cold-free space as a factor of invasive success. Ann Entomol Soc Am. 2008; 101(5): 860-866.

65. Hodek I. Diapause/Dormancy. In: Hodek I, Honek A, Van Emden HF, editors. Ecology and Behaviour of the Ladybird Beetles (Coccinellidae). John Wiley \& Sons. 2012. pp. 275-342.

66. Lucas E, Coderre D, Brodeur J. Intraguild predation among aphid predators: Characterization and influence of extraguild prey density. Ecology. 1998; 79(3): 1084-1092.

67. Lucas É, Rosenheim JA. Influence of extraguild prey density on intraguild predation by heteropteran predators: A review of the evidence and a case study. Biol Control. 2011; 59(1): 61-67.

68. Finke DL, Denno RF. Intraguild predation diminished in complex-structured vegetation: implications for prey suppression. Ecology. 2002; 83(3): 643-652.

69. Janssen A, Sabelis MW, Magalhães S, Montserrat M, Van der Hammen T. Habitat structure affects intraguild predation. Ecology. 2007; 88(11): 2713-2719

70. Moser SE, Harwood JD, Obrycki JJ. Larval feeding on Bt hybrid and non-Bt corn seedlings by Harmonia axyridis (Coleoptera: Coccinellidae) and Coleomegilla maculata (Coleoptera: Coccinellidae). Environ Entomol. 2008; 37(2): 525-533.

71. Mills NJ, Beers EH, Shearer PW, Unruh TR, Amarasekare KG. Comparative analysis of pesticide effects on natural enemies in western orchards: A synthesis of laboratory bioassay data. Biol Control. 2016; 102: 17-25. 
bioRxiv preprint doi: https://doi org/10.1101/349852; this version posted June 18, 2018. The copyright holder for this preprint (which was not certified by peer review) is the author/funder, who has granted bioRxiv a license to display the preprint in perpetuity. It is made available under aCC-BY 4.0 International license.

568 72. Lefebvre M, Bostanian NJ, Mauffette Y, Racette G, Thistlewood HA, Hardman JM.

569 Laboratory-based toxicological assessments of new insecticides on mortality and fecundity of Neoseiulus fallacis (Acari: Phytoseiidae). J Econ Entomol. 2012; 105(3): 866-871. 
Intraguild predator (L2) Intraguild prey (L1)

Intraguild prey treated with water
C. maculata

\section{H. axyridis}

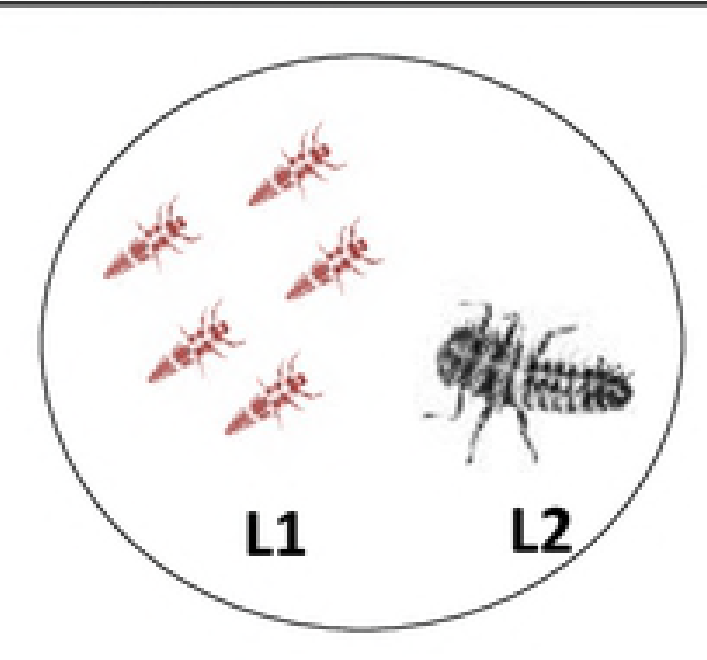

H. axyridis

C. maculata

Intraguild prey treated with insecticide (novaluron)
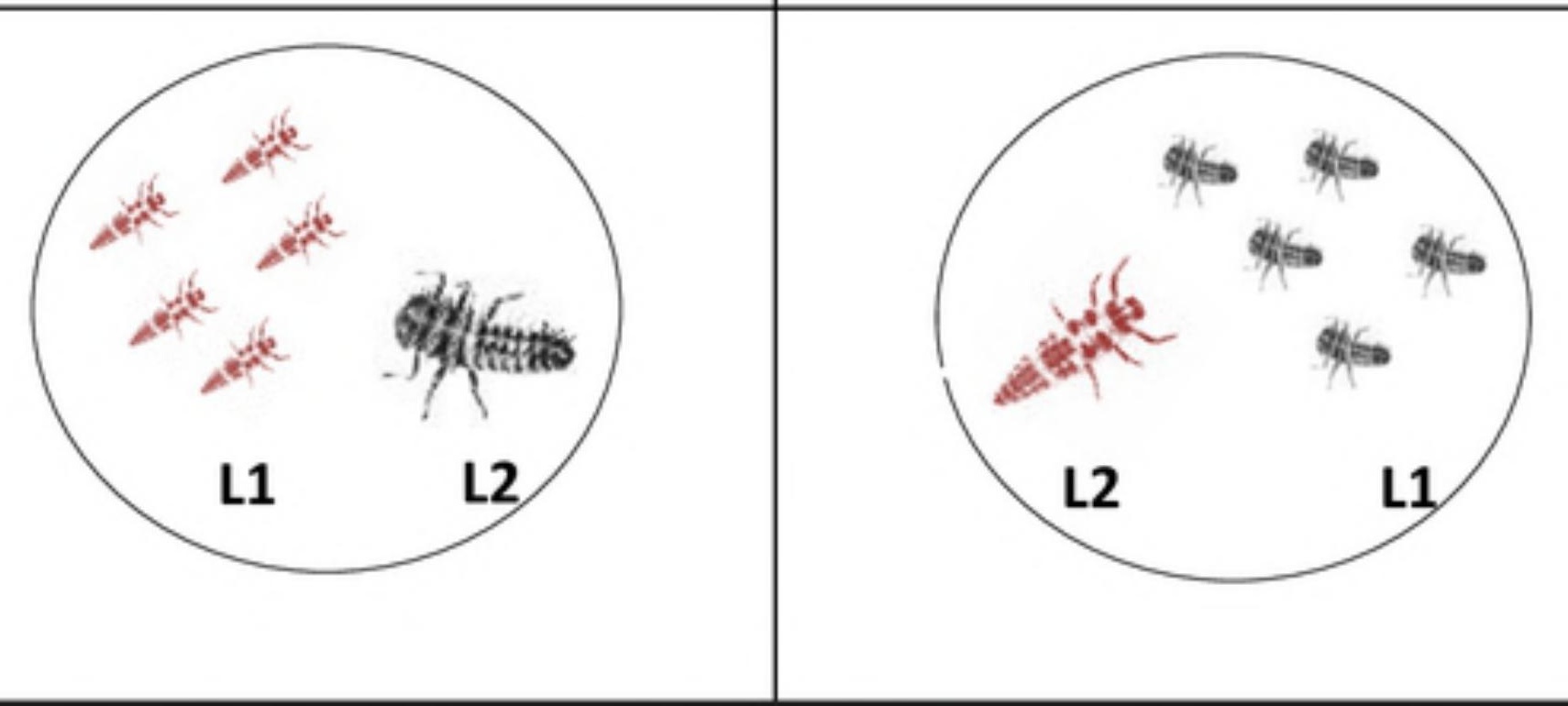
bioRxiv preprint doi: https://doi.org/10.1101/349852; this version posted June 18, 2018. The copyright holder for this preprint (which was not certified by peer review) is the author/funder, who has granted bioRxiv a license to display the preprint in perpetuity. It is made available under

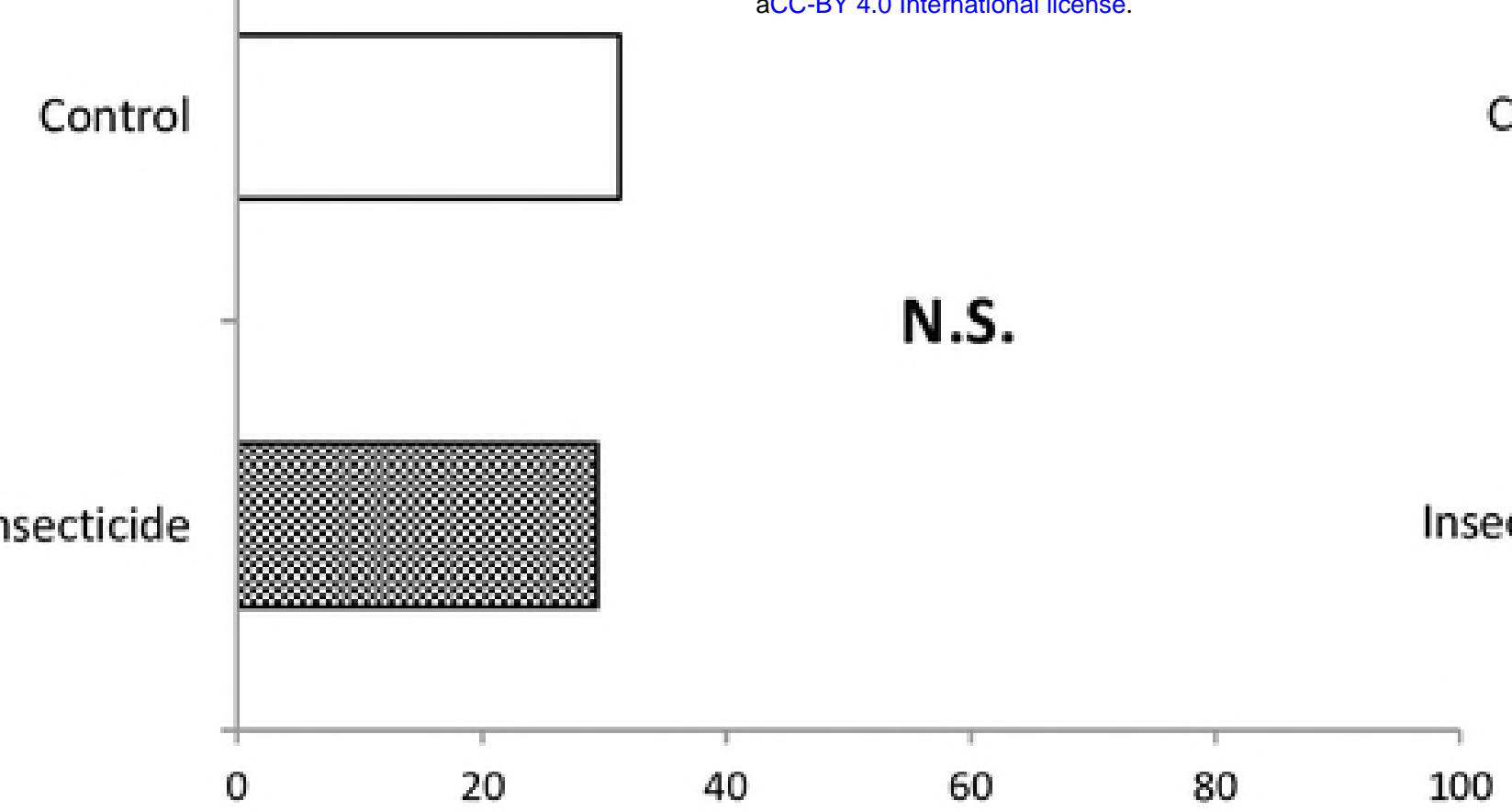

Mortality of the indigenous ladybeetle as the IG predator (\%)

Mortality of the invasive ladybeetle as the IG predator (\%)

\section{c) Control}

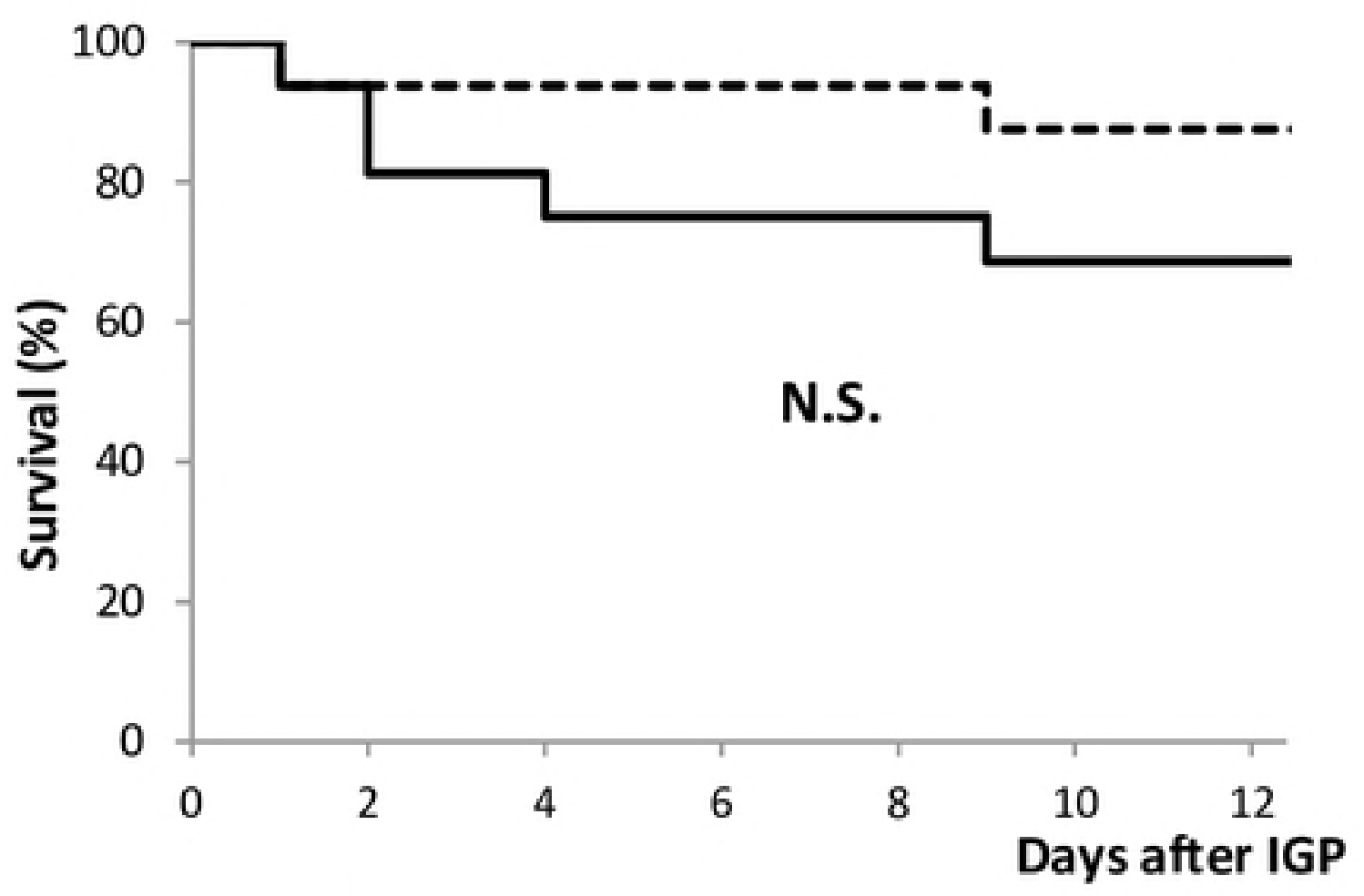

d) Insecticide

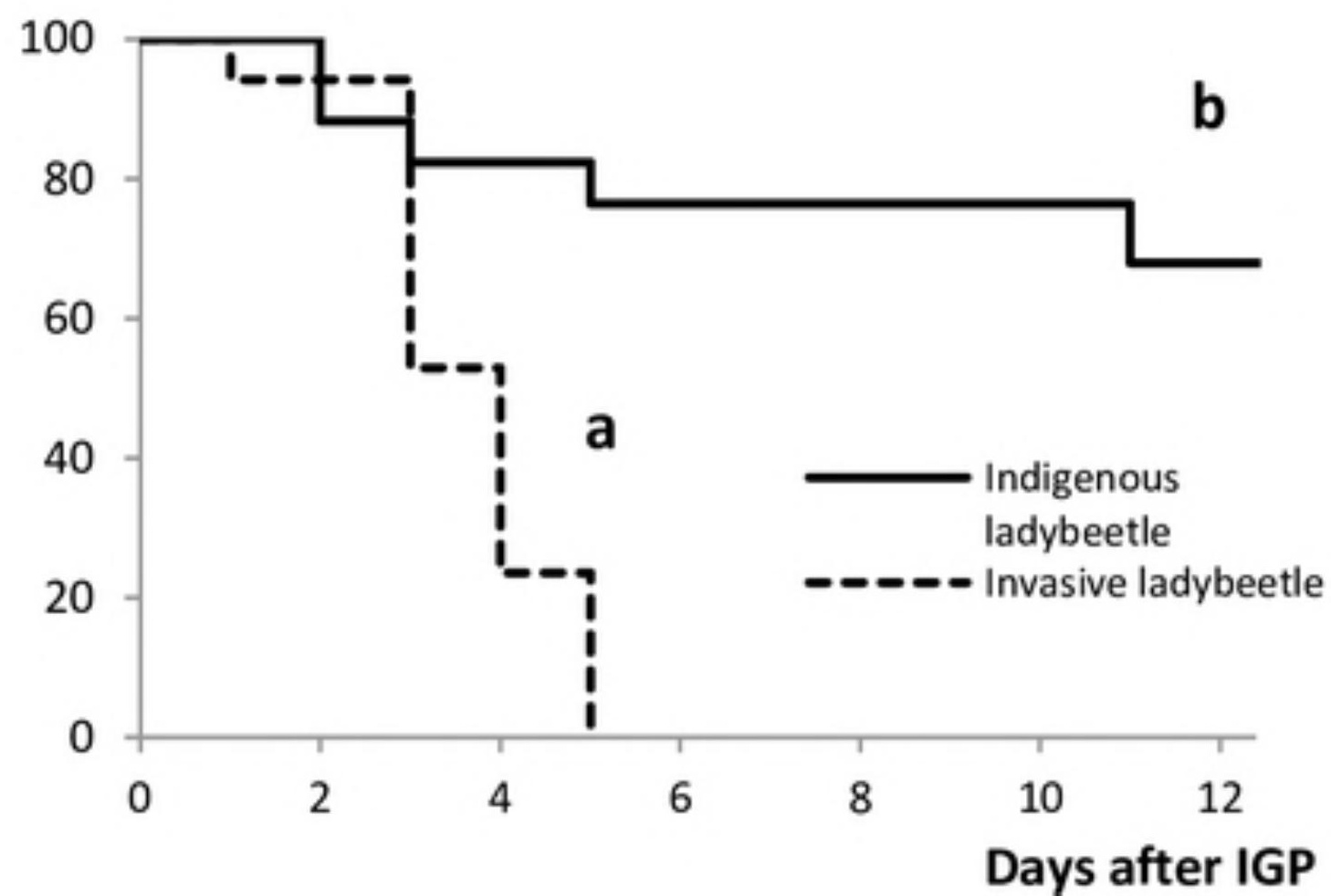




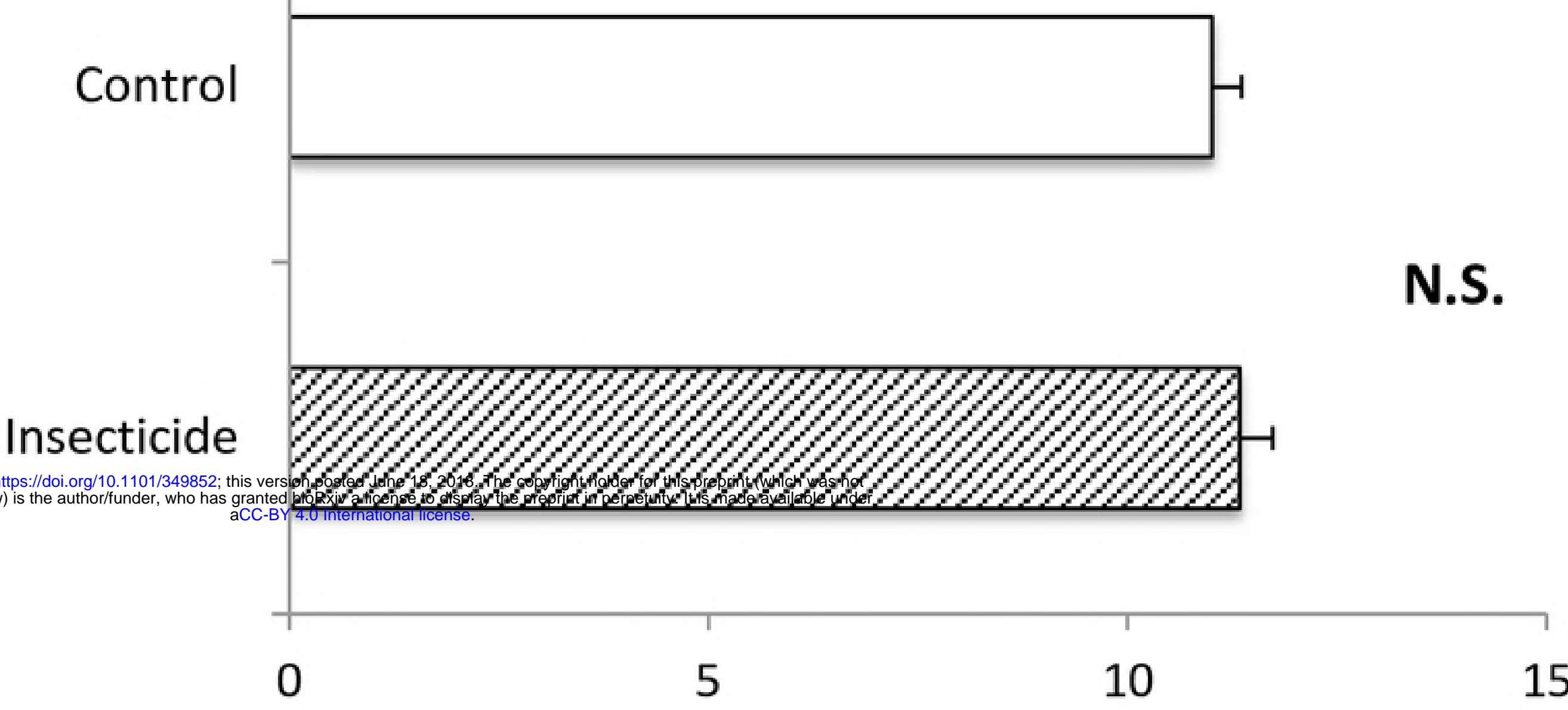

Time of development (days after IGP)

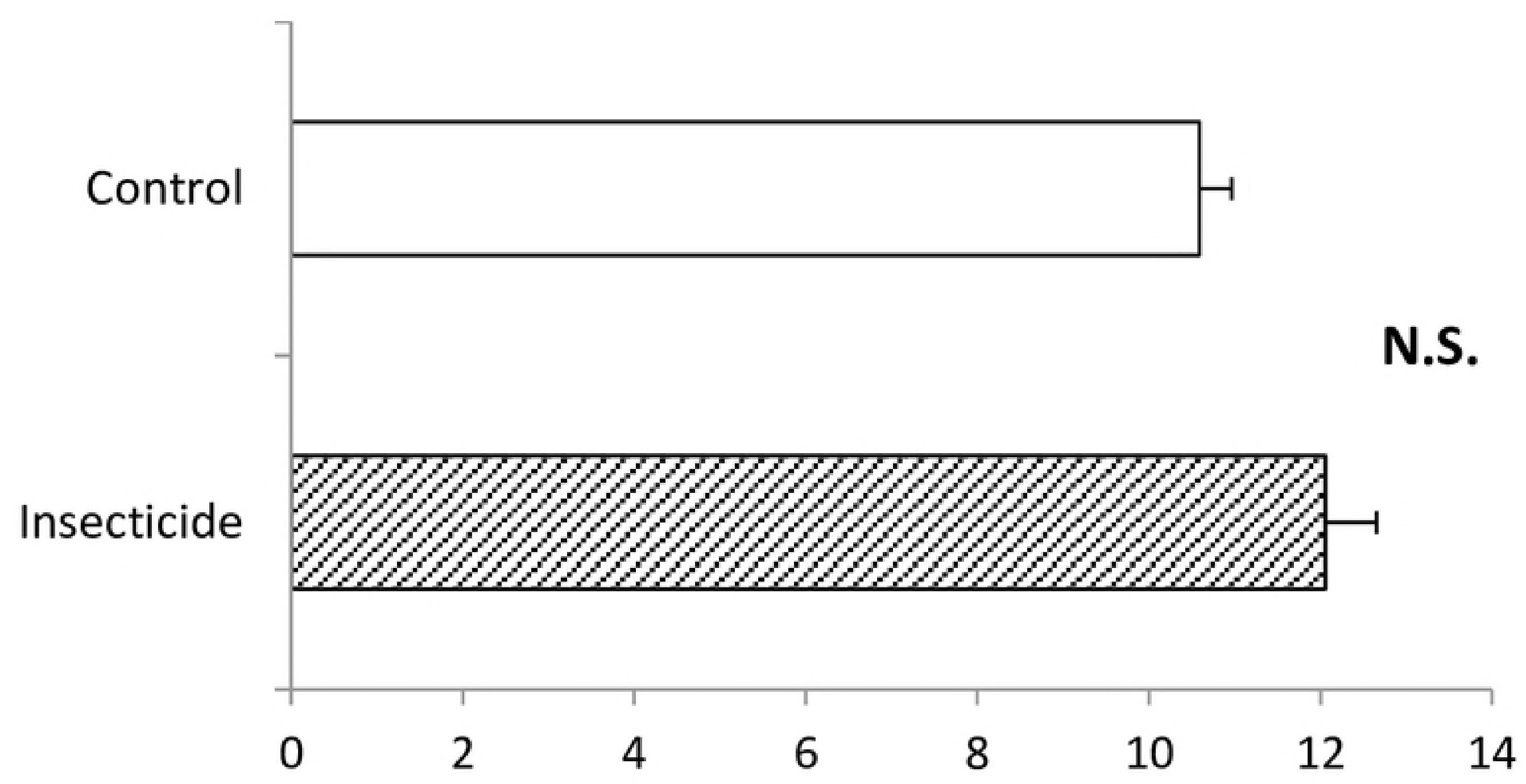




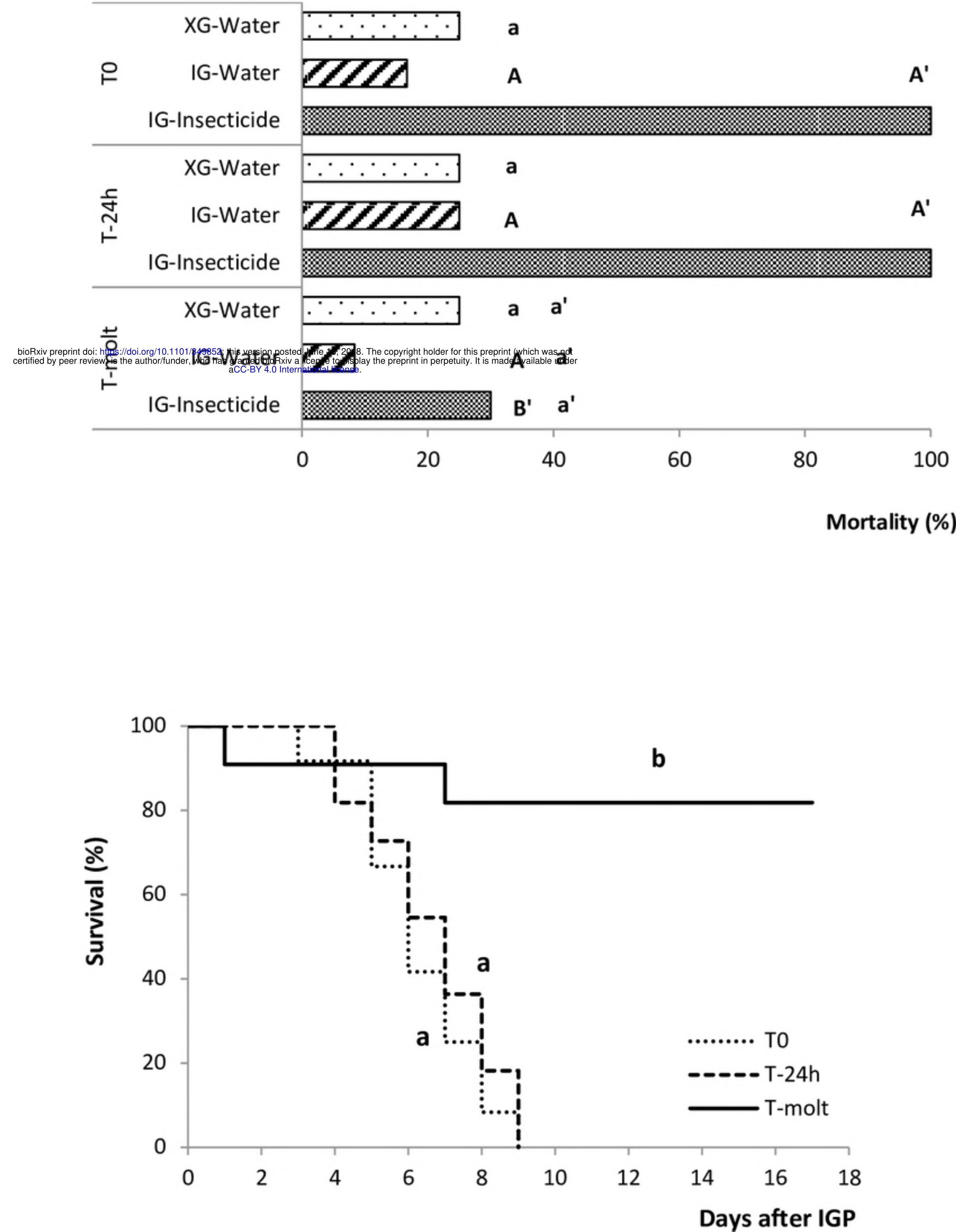

b)

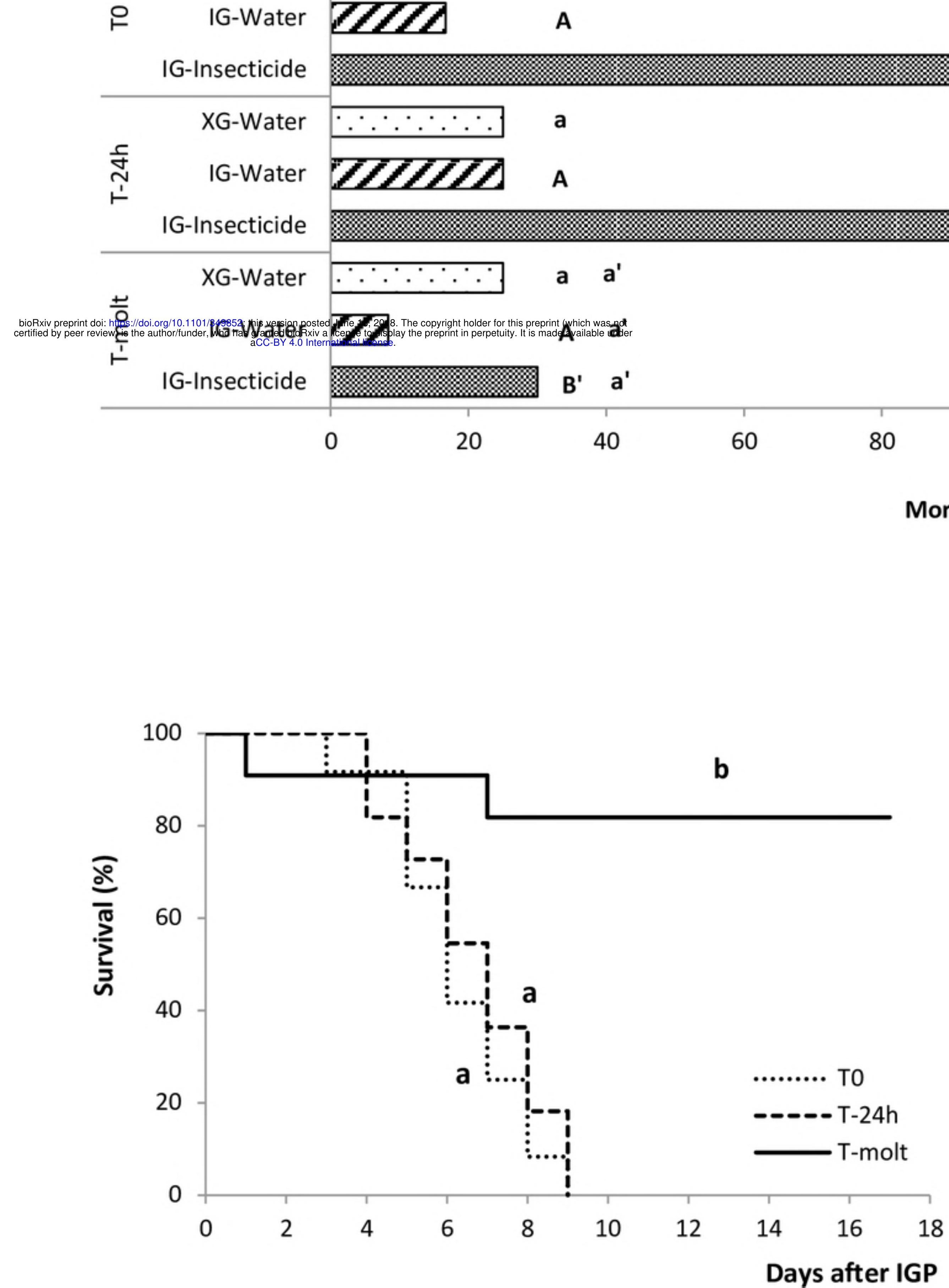

Mortality (\%) 
